\title{
Impact of Training and Development on Employee Job Performance in Nigeria
}

\author{
Mary Vincent \\ Department of Public Administration, Adamawa State Universty, Mubi Nigeria
}

DOI: $10.36348 /$ sjhss.2020.v05i05.004 $\quad$ | Received: 18.05 .2020 | Accepted: 26.05 .2020 | Published: 30.05 .2020

*Corresponding author: Mary Vincent

\section{Abstract}

This study focuses on the impact of training and development on employee's job performance in Nigeria. Training and development is a critical process, which seeks to improve the performance of workers in an organization. The study defined the concept of staff training and development; it identified stages in organizing staff training and development such as orientation, in service programme, job rotation and in-house training. The study establishes the importance of staff training and development in organizations which include rapid economic development, promotion of political stability and poverty alleviation. The challenges of staff training and development are poor political leadership and poor staff training. In conclusion, training has been invaluable in increasing productivity of organizations. It does not only enhance employees resourcefully, but also provides them with an opportunity to virtually learn their jobs and perform more competently. It is recommended that training programmes of the organization should be on a continuous basis and not only when the organization is confronted with difficulties.

Keywords: Employees' training, staff development; human capital; work performance and attitude to work.

Copyright @ 2020: This is an open-access article distributed under the terms of the Creative Commons Attribution license which permits unrestricted use, distribution, and reproduction in any medium for non-commercial use (NonCommercial, or CC-BY-NC) provided the original author and source are credited.

\section{Concept of Staff Training and Development}

Training and development are complementary parts of the same process. They are interlinked and interdependent, rather than sequential and hierarchical. Training and development is very crucial to the employees, the organization and their effectiveness [1]. Training and development activities are important elements of the human resource management function of an organization. Training and development refers to the practice of providing training, workshops, coaching, mentoring, or other learning opportunities to inspire, challenge, and motivate employees to perform the functions of their position to the best of their ability and within standards set by local, state, federal and private organization. Training makes employees feel that they are part of the organization's family; it creates the sense of belonging in all employees; it creates the professional development and enhances the employee's skills; it also makes knowledgeable workforce with fewer mistakes.

Training and development should be viewed as opportunity for growth, but investment that yields overall returns and benefits to organizations and employees. It is about managing and empowering people, the vital assets of any business or firm
According to Neelam [2], in contributing to the overall goal of the organizations, training and development leads to improved profitability while cultivating more positive attitudes towards profit orientation. For the individuals, training and development improve job knowledge while also helping in identifying with the goal of the organizations. Training and development enables managers to help employees perform better in the work and keep them motivated. This will strengthen individual and organizational performance and further the organization's ability to meet its goals according to performance objectives and standards despite internal and external challenges to the organization

\section{Stages in Organizing Staff Training and Development Programme}

The stages, tools and methods for staff training in organizations differs, and it is largely determined by the objectives of organizations, the idiosyncrasy of management staff or the chief executive, the organizational policy, as well as the organizational environment to mention a few. Thus, it is a common feature to see methods for staff varying from one organization to the other, just as a given organization can be tailored at adopting different methods at different times or a combination of techniques at the 
same time. However, some methods for staff training are stated below:

Orientation: This method of staff training could be said to be an integral part of the recruitment exercise in that once an employee has been found eligible, it is expected that such an employee need to be positively oriented in line with the vision and aspiration of the organization for effective discharge of function. Since employee function in an organization is basically affected by his perception of the organization viz-a-viz the rules and principles that exist in the organization. It therefore follow that an employee undergoes formal and informal orientation in a place of work. While the formal orientation focuses on job specification and occupational demands placed on the employee, the informal orientation involve the social interaction that take place in the place of work which could either boost productivity or be detrimental to it. Orientation therefore is a method of staff training is quite indispensable because it helps in boosting the productivity of workers which is needed for competing in the global market of the $21^{\text {st }}$ century.

\section{On the job method of Staff training}

This method is basically different from the orientation method in that while orientation is at the point of entry into the organization or a new assignment; on the job method is processes through which knowledge and experience are acquired over a period of time either formally or informally. This process according to Yalokwu [3] and Lawal [4] involves the following:

Coaching: this is a method of on the job staff training and in which a young employee is attached to a senior employee with the purpose of acquiring knowledge and experience needed for the performance of tasks.

Job Rotation: this method either involves the movement of an employee from one official assignment or department to the other, in order for the employee to be acquainted with the different aspects of the work process or through job enlargement. That is given additional responsibility to an employee who has been uplifted as a result of the acquisition of additional skill or knowledge.

In House Training: this involve a formal method of on the job staff training in which skills and knowledge are acquired by employees through internally organized seminars and workshops geared toward updating the workers with new techniques or skills associated with the performance of their jobs.

In Service Training: this method involve staff training outside the organization or workplace in higher institution of learning or vocational centres under the sponsorship of the organization or on terms that may be agreed upon between the organization and the worker.

Committee/Work Group Method: This method entails staff training through the involvement of employees in meetings, committees and work group discussion geared towards injecting inputs in form of decision making as regard solving organizational problem. This method is quite indispensable, especially in the aspect of staff training employees for managerial functions or heading organizational units.

Vestibule Staff Training Method: This is a method of Staff training through the acquisition of skills in a related working environment. Under this method the trainee practices his skill with identical equipment that he uses or he is expected to use in his actual place of work. This method is most suitable for sensitive operations where maximal perfection is expected. The purpose is therefore to enable perfection at work place.

Apprenticeship Method: This method of staff training involves the acquisition of skill through extensive practice for over a period of time by the trainee. This type of staff training device could either be formal or informal. In the informal environments the trainee is attached to the trainer, and he/she is expected to pay for an agreed period of apprenticeship. The formal environment on the other hand is where an employee of an organization could be placed under apprenticeship in the organization with pay.

\section{Importance of Staff Training and Development in Organizations}

Economic Development: The relevance of staff training in Nigeria could be situated vis-à-vis economic development. It involves the building of capacity and harnessing the states human resources which constitute a sine-qua-non for development. Clearly a country which is unable to develop the skills and knowledge of it people and to utilize them effectively in the national economy will be unable to develop anything else.

Political Stability: There is no doubt that a country which fails to adequate develop her staff would be doing so at the expense of her socio economic and political stability. In the aspect of political stability [5] stressed the dysfunctional use of the nation human resources among the youth in propelling political instability when he stated that: there has been a situation in which the Nigerian youth especially, those of poor family background were used as tools for disrupting the political democratic system through rigging by thugery and ethnic conflicts. Hence, staff training could help the youth in the development of self and improving the quality of their political participation.

Poverty alleviation: It has been argued that effective poverty alleviation scheme must involve the 
development and utilization of local resources including human for solving local problem. Thus, staff training is central to solving the present problem of poverty in Nigeria.

\section{Problems of Staff Training in Nigeria}

Colonial Experience: There have been several arguments regarding the distortions in staff training of nation growth in Nigeria as a result of colonialism which was fashioned towards economic exploitation [7]. During the advent of colonialism led to the integration of the Nigeria economy into the World capitalist system thereby placing minimum premium on labour when compared to other factors of production. This poor performance of indigenous labour by the colonial government no doubt has persisted in the postcolonial Nigerian state. As a result, this problem account for the lack of adequate attention given to labour as a critical part of the production process in Nigeria.

Poor Political Leadership: Closely related to the problem of colonial experience as a staff training in Nigeria is poor political leadership which is further deepening the problem of staff training in Nigeria.

Poor Staff Training: This problem is associated with the poor data base that is needed for staff planning in Nigeria both in the rural and urban centres. These problem no doubt constitute a major hindrance on effective staff training.

\section{Impact of Staff Training and Development on Employee Job Performance}

Training has been invaluable in increasing productivity of organizations. It does not only enhance employees resourcefully, but also provides them with an opportunity to virtually learn their jobs and perform more competently. Various researches indicate the positive impact of training on employees' productivity. Training as a process is one of the most pervasive methods to enhance the productivity of individuals and communicating organizational goals to personnel. Rohan and Madhumita [7] also supported that investing in training employees on decision making, teamwork, problem-solving and interpersonal relations has beneficial impact on the organizations' level of growth, as well as impacting on employees' performance. Training affects employees' behavior and their working skills which results into employees enhanced performance as well as constructive changes.

Training is most effective way of motivating and retaining high quality in human resources within an organization. It is a way of enhancing employee commitment and maximizing employee potential. According to Konings and Vanormelingen [8], training is an instrument that fundamentally affects the successful accomplishment of organizations' goals and objectives. However, the optimum goal of every organization is to generate high revenue and maximize profit and a vital tool to realize this is an efficient and effective workforce. Thus, a workforce is only efficient and effective if the appropriate training and development is provided for such and therefore leading to productivity.

Training is the crucial area of human resource management; it is the fastest growing segment of personnel activities. Training which is referred to as a course of diet and exercise for developing the employees' effective, cognitive and psychomotor skills assist the organizations to have a crucial method of developing the employees' towards enhancing his productivity [9]. Manpower training and development is one of the most important organizational dynamics. It constitutes the pivot in which organizational survival is run. The training process is one of the most pervasive methods for enhancing the productivity of individuals and communicating organizational goals to personnel. Training is transferring information to organization's members to positively improve the effectiveness and productivity of organizations. Training enables organizations to act more effectively because of having valued employees $[10,11]$.

Evaluating the impact of investments in people (such as training) helps to justify the costs incurred, validate the intervention as a business tool, and aid the design and selection of future investment methods. Evaluation is a systematic process of determining the significance or worth of subject, using criteria governed by a set of standards. It can assist an organization to ascertain the degree of achievement or value in regards to the aim and objectives of an undertaken project. The primary aim of evaluation, apart from gaining insight into prior or existing initiatives, is to enable reflection and assistance in the identification of future change [12].

\section{CONCLUSION}

Training may lead to better performance if employees are provided with complementary inputs/resources. However, any programme not guided by clear policy is prone to implementation setbacks. The absence of clear policy puts matters to chance and miracles cannot be expected. Through training, knowledge, skills and change in attitudes are imparted which enhance confidence, competence and commitment respectively. It is apparent that performance of individual is jointly influenced by ability and training. Thus training influences performance through ability factor and plays only partial role in determining the overall level of individual performance. Whereas training is necessary to develop and maintain internal efficiency of organisation, the supply of training input in itself may not guarantee improved performance unless other factors that need to complement training are addressed. 


\section{RECOMMENDATIONS}

- There is need to conduct training needs assessment to ensure that the right training is given. This will enhance the competitiveness of the staff as they will be equipped with necessary competences and current trends within the organization.

- Training programmes of the organization should be on a continuous basis and not based on survival, that is, conducting training only when the organization is confronted with particular problems.

- Staff who performed exceptionally well during training sessions should be motivated or rewards for such outstanding performances as this will spur other staff into action and may certainly nurture an inbuilt desire to excel, which will ultimately impact positively on the general performance of staff.

- The entire management and administration of the organization should be in the hands of professionals and experiences in the field. In order words political favoritism should be avoided, if standard and quality is to be maintained.

- Governmental and private organizations should increase the tempo of capacity building and staff development as it will increase productivity and result into nation building.

\section{REFERENCES}

1. Devi, V. R., \& Shaik, N. (2012). Training and development: A jump starter for employee performance and organizational effectiveness. International Journal of Social Science and Interdisciplinary Research, 1(7) July, 2277-3630.

2. Neelam, T. (2014). The impact of training and development on employee's performance and productivity: A case study of United Bank Limited Peshawar city, KPK, Pakistan. International Journal of Academic Research in Business and Social Sciences, 4(4),86-98.

3. Yalokwa, P. O. (2002). Manpower, concept and techniques. Lagos, Peak Publishers.
4. Lawal, M. M. (2006). Manpower management: A handbook for managers and students of Administration. Abuja, Roots, Books and Journals Nigeria Limited.

5. Omodia, S. M. (2009). Manpower development in Nigeria conceptual and methodological perspectives. Journal of Social Science, 18(2), 113-117.

6. Dauda, M. (2003, September). 2003. In Solid waste management and re-use in Maiduguri, Nigeria. IN: Harvey, P.(ed). Towards the millennium development goals-Actions for water and environmental sanitation: Proceedings of the 29th WEDC International Conference, Abuja, Nigeria (pp. 20-23). cc WEDC, Loughborough University.

7. Wilmot, E. G., Edwardson, C. L., Achana, F. A., Davies, M. J., Gorely, T., Gray, L. J., ... \& Biddle, S. J. (2012). Sedentary time in adults and the association with diabetes, cardiovascular disease and death: systematic review and meta-analysis.

8. Konings, J., \& Vanormelingen, S. (2009). The impact of training on productivity and wages: firm level evidence. Discussion paper No. 244, Available at SSRN.

9. Ezeani, N. E., \& Oladele, R. (2013). Implications of training and development programmes on accountant's productivity in selected business organizations in Onitsha, Anambra State, Nigeria, International Journal of Asian Social Science, 3(1), 266-281.

10. Leard, G. (2010). Benefits of training for both the organization and employees, Helium online Available

at http://www.helium.com.items/1774143-trainingand-its-benefits-why-training-workers-is-trainingnecessary

11. National Open University of Nigeria. (2013). Principles of personnel management. ( Lecture material). ISBN, 978-058-172-3 online. Available at https://www.nou.ng//NOUN

12. ICAP. (2012). What is evaluation? International Center for Alcohol Policies. http://www.icap.org/PolicyTools/Toolkits/Evaluati onToolkit/ 2WhatIsEvaluation,[accessed 22 May 2012]. 